\title{
Oesophageal variceal bleeding in Felty's syndrome associated with nodular regenerative hyperplasia
}

\author{
L. M. BLENDIS, D. LOVELL, C. G. BARNES, S. RITLAND, D. CATTAN, \\ AND P. VESIN
}

From the Department of Medicine, Toronto General Hospital, Canada; Department of Histopathology, Central Middlesex Hospital, London; Department of Rheumatology, the London Hospital; Medical Department A, Rikshospitalet Oslo; and Department of Gastroenterology, Hôpital de Villeneuve-Saint Georges, University of Creteil, France

SUMMARY Four patients with Felty's syndrome developed massive upper gastrointestinal bleeding due to oesophageal varices. The underlying hepatic pathology in all 4 was nodular regenerative hyperplasia. This appears to be a difficult histological diagnosis to make, having been initially reported as normal on percutaneous biopsy or as fibrosis or cirrhosis on wedge biopsy. This series brings the total number of cases reported in the English literature of this association to 12, suggesting a definite symptom complex. The portal hypertension seems to be due to a combination of increased splenic blood flow and postsinusoidal resistance. The clinical importance of this syndrome is that the appropriate therapy for bleeding oesophageal varices appears to be shunt procedure such as a splenorenal shunt with splenectomy, which should be well tolerated.

In the past few years increasing interest has been shown in the hepatic abnormalities in Felty's syndrome. Abnormal liver function tests were found in 8 of 12 consecutive patients with this syndrome, 4 of whom had lymphocytic infiltration of sinusoids and portal tracts and 1 macronodular cirrhosis (Blendis et al., 1970a). There have since been reports of associated portal fibrosis (Barnes et al., 1971), and cirrhosis (Ritland, 1973) in patients with Felty's syndrome. Recently, 5 patients with Felty's syndrome were described who had nodular regenerative hyperplasia of the liver (Blendis et al., 1974).

Accepted for publication August 10, 1977

Correspondence to Dr L. M. Blendis, 1st Floor, University Wing, Toronto General Hospital, Toronto, Ontario, Canada M5P 2J2
One of these died from massive haemorrhage from oesophageal varices.

We have collected 4 cases of Felty's syndrome with oesophageal variceal bleeding. 3 of the patients have been reported previously, 2 with incorrect liver diagnoses, showing the changes of nodular regenerative hyperplasia.

\section{Case reports}

\section{CLINICAL FEATURES}

Details of the haematological and rheumatological investigations on the 4 patients are given in Table 1, which illustrates the pancytopenia, the nodular seropositive form of rheumatoid arthritis, and the high incidence of multiple system involvement. The

Table 1 Clinical data of 4 patients with rheumatoid arthritis and Felty's syndrome

\begin{tabular}{|c|c|c|c|c|c|c|c|c|c|c|c|}
\hline $\begin{array}{l}\text { Case } \\
\text { no. }\end{array}$ & $\begin{array}{l}\text { Age } \\
\text { (years) }\end{array}$ & Sex & $\begin{array}{l}\text { Duration of } \\
\text { arthritis } \\
\text { (years) }\end{array}$ & Nodules & $\begin{array}{l}S C A T \\
(\text { Latex })\end{array}$ & $\begin{array}{l}E S R \\
(\mathrm{~mm} / \mathrm{h})\end{array}$ & $\begin{array}{l}\text { Complication, } \\
\text { multisystem } \\
\text { involvement }\end{array}$ & $\begin{array}{l}H b \\
(g / d l)\end{array}$ & $\begin{array}{l}W B C \\
\left(\times 10^{9} / l\right)\end{array}$ & $\begin{array}{l}\text { Neutophils } \\
\left(\times 10^{9} / I\right)\end{array}$ & $\begin{array}{l}\text { Platelets } \\
\left(\times 10^{9} / l\right)\end{array}$ \\
\hline 1 & 74 & $\mathbf{F}$ & 20 & + & $\begin{array}{l}256 \\
(+)\end{array}$ & 132 & $\begin{array}{l}\text { Rheumatoid lung; } \\
\text { renal } \\
\text { amyloidosis }\end{array}$ & $7 \cdot 1$ & $1 \cdot 8$ & 0.54 & 80 \\
\hline 2 & 54 & $\mathbf{F}$ & 9 & + & $\begin{array}{l}256 \\
(+)\end{array}$ & 68 & $\begin{array}{l}\text { Sjøgren's } \\
\text { syndrome; } \\
\text { rheumatoid lung }\end{array}$ & $10 \cdot 1$ & $2 \cdot 2$ & 0.79 & 61 \\
\hline 3 & 72 & $\mathbf{M}$ & 6 & + & $(-)$ & 25 & $\begin{array}{l}\text { Transient renal } \\
\text { tubular acidosis }\end{array}$ & $11 \cdot 5$ & $2 \cdot 1$ & $1 \cdot 36$ & 74 \\
\hline 4 & 65 & $\mathbf{F}$ & 21 & + & $(+)$ & 17 & - & $11 \cdot 1$ & $1 \cdot 8$ & 0.83 & 50 \\
\hline
\end{tabular}


hepatological features are given in Table 2. None of the 4 patients had clinical stigmata of chronic liver disease. 3 patients had hepatomegaly in addition to splenomegaly but little alteration of liver function. 3 of the 4 had significant portal hypertension on measurement of portal pressure.

\section{CASE $1^{*}$}

A 74-year-old woman was known to have had rheumatoid arthritis for at least 20 years. Proteinuria due to renal amyloidosis had been present for 7 years. In 1971 she was admitted as an emergency after a haematemesis. Laparotomy showed large tortuous veins in the falciform ligament. The surface of the liver appeared normal. After gastrostomy large oesophageal varices were seen. A bleeding point was identified and under-run, but the patient continued to bleed, and since her clinical condition precluded further surgery a Sengstaken tube was passed. This controlled the bleeding for a further 3 days, but she then had a massive haematemesis when the balloon was deflated, and died.

\section{CASE $2 \dagger$}

A 54-year-old woman had had seropositive erosive rheumatoid arthritis for 9 years. In 1965 she had an episode of erythema, pleuritic pain, and developed a pleural effusion which cleared spontaneously. The following year she was found to have hepatosplenomegaly. Investigation shows a pancytopenia and slightly abnormal liver function tests but all other tests, including a liver biopsy, were normal. Persistent inflammatory polyarthropathy and fever, together with the previous findings, led to a trial of cyclophosphamide therapy. 2 years later she was admitted with a massive haematemesis and required transfusion with 20 pints of blood. At laparotomy the portal pressure was found to be markedly raised (Table 2). Splenectomy and splenorenal anastomosis

*First reported by Blendis et al. (1974).

$\dagger$ †irst reported by Barnes et al. (1971). were performed. The liver was not cirrhotic it appearance and histological examination subse quently showed nodular regenerative hyperplasia. (Fig. 1).

\section{CASE 3}

A 72-year-old man had had rheumatoid arthritis for 6 years and Felty's syndrome for 3 years. In June 1975, he presented with sudden onset of haematemesis and melaena shown to be due to oesophageál varices on oesophagoscopy. On examination, $\vec{m}$ addition to rheumatoid changes, he had a palpable spleen but the liver was not enlarged. Liver scas showed no evidence of cirrhosis. Laparoscopy wa performed, a normal liver was seen and a biopsy taken. After further haematemesis, he developed :a transient mild hyperchloraemia acidosis. Serunt? bicarbonate $20 \mathrm{mmol} / \mathrm{l}$, chloride $112 \mathrm{mmol} / \overrightarrow{\mathrm{d}}$ sodium $141 \mathrm{mmol} / 1$, potassium $3.2 \mathrm{mmol} / 1$; am inappropriately alkaline urine of $\mathrm{pH} 8.3$ to 8.5 associated with increased urinary bicarbonate excretion of 10 and $8 \mathrm{mEq} / 24 \mathrm{~h}$ on two successise days (normal 0-5). Before further studies could be performed, the acidosis disappeared associated wit a return of urinary $\mathrm{pH}$ to 6 . He was discharged frofi hospital well, only to be admitted to another hospitg with a further haematemesis. A portacaval shum was performed but he died in the postoperative period.

\section{CASE $4_{+}^{+}$}

A woman, aged 65 years, began to complain of joight symptoms 20 years previously. She was treated with phenylbutazone for 2 years in doses between 600 an $200 \mathrm{mg}$ daily, and was admitted with a history of anaemia and chronic gastrointestinal bleeding. Examination showed hepatosplenomegaly, ang pancytopenia attributed at the time to pheny butazone. 3 years later she had a haematemesis. Splenic venography showed oesophageal varices and

†First reported by Ritland (1973).

Table 2 Clinical and biochemical findings relevant to the liver involvement in Felty's syndrome

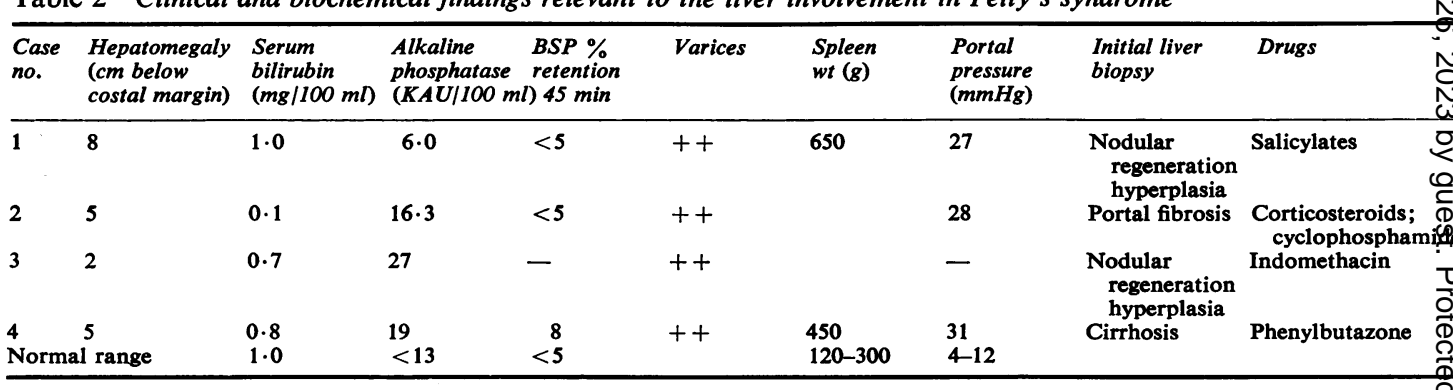

BSP = bromsulphalein. Conversion: Traditional units to $S I$-Bilirubin: $1 \mathrm{mg} / 100 \mathrm{ml} \approx 17 \cdot 1 \mu \mathrm{mol} / 1$. 


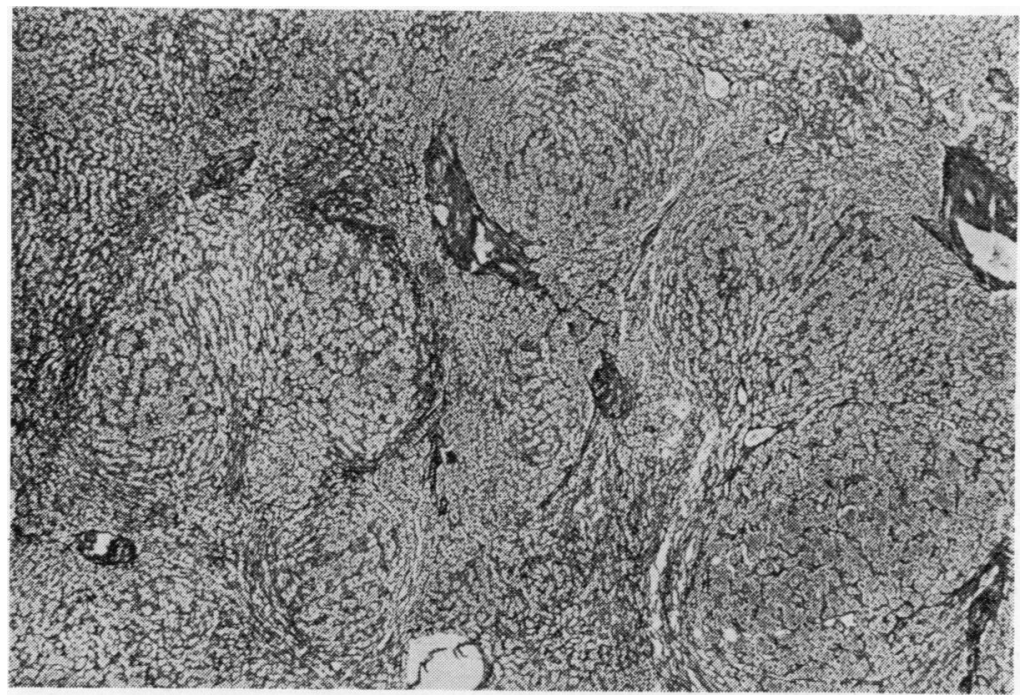

Fig. 1 Case 2. Photomicrograph showing an apparently marked liver nodularity, due to condensation of reticulin fibres but with no increase in collagen. Reticulin stain $\times 25$.

the intrasplenic pressure was raised (Table 2). Splenectomy and splenorenal anastomosis were performed. Liver biopsy was initially interpreted as cirrhosis (Ritland, 1973) (Fig. 2). Postoperatively, the leucocyte count rose to $9.0 \times 10^{9} / 1$ and the platelets to $165 \times 10^{9} / 1.4$ years later there has been no deterioration in liver function and no further bleeding.

\section{Discussion}

Nodular regenerative hyperplasia (NRH) as originally described (Steiner, 1959) is a difficult histological diagnosis to make as confirmed in the present report

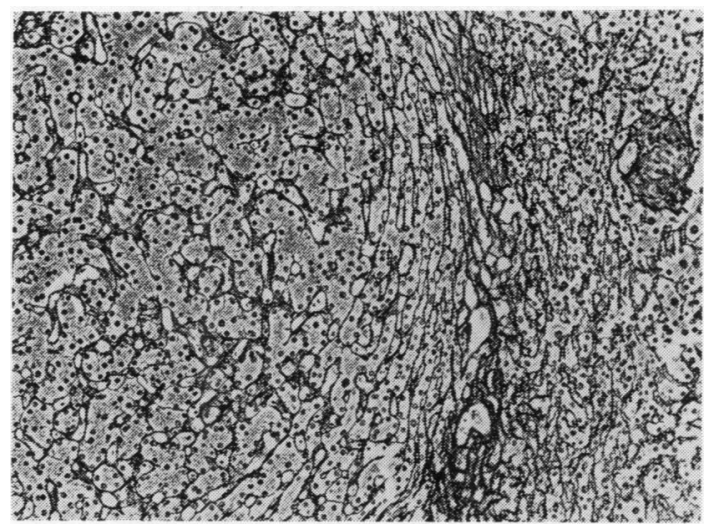

Fig. 2 Case 4. High power photomicrograph of a 'nodule' showing retention of architecture with compression and realignment of cells at periphery of nodule. Reticulin stain $\times 55$. in which 2 of the 4 cases were originally diagnosed as portal fibrosis (Barnes et al., 1971) or cirrhosis (Ritland, 1973). The surface of the liver may appear normal, finely granular or nodular, and on histology the 'nodules' are not outlined by true fibrosis giving a negative stain for collagen with Mallory's trichrom. Another important feature is the reversal pattern of the hepatic vein radicle and the lobule, so that the vein may be found in the periphery of the nodule within the circular compressed columns of hepatocytes. This histological pattern is usually not apparent on the small amount of tissue produced by a percutaneous liver biopsy when the liver may appear normal. The aetiology of NRH remains obscure.

Recent publications have drawn attention to the association of a related noncirrhotic nodular condition of the liver, focal nodular hyperplasia, with oral contraceptives (Stauffer et al., 1975). However, all 4 patients in this series were on different drugs.

The association of NRH with Felty's syndrome is becoming increasingly recognised. In addition to the 3 new cases in this report, we have heard of 2 further patients with this association (Knowles et al., 1975; Reisman et al., 1977), bringing the total number of cases in the English literature up to 12 out of approximately 26 cases of NRH so far reported (Blendis, 1978). 12 of the remaining patients had congestive cardiac failure, 1 had subacute bacterial endocarditis (Knowles et al., 1975), and 1 had rheumatoid arthritis with no evidence of Felty's syndrome (Harris et al., 1974). This last patient presented with ascites, developed encephalopathy after abdominal paracentesis, and at necropsy the liver was small. 
She was atypical in many respects from the patients described in this report, none of whom developed encephalopathy even after massive gastrointestinal bleeding.

Thus the question as to whether Felty's syndrome and NRH is a definite syndrome complex will depend on whether Felty's is a specific syndrome complex within the spectrum of rheumatoid arthritis. Although this question remains controversial, a recent report of the occurrence of NRH in 3 members of one family with Felty's syndrome (Blendis et al., 1976) supports the suggestion that it is a definite entity. However, the association of Felty's syndrome and NRH cannot explain the splenomegaly and 'hypersplenism' in most patients with this syndrome. For example, only one of 6 Felty's patients coming to necropsy had NRH on histological examination of the liver (Barnes et al., 1971).

The mechanism of portal hypertension in this condition has previously been shown to be due partly to increased splenic blood flow (Blendis et al., 1974), which particularly in noncirrhotic patients results in an increase in portal blood flow (Blendis et al., 1970b), and partly to an unexplained postsinusoidal resistance. The latter may be due to distortion and compression of the intrahepatic venous radicles or to microthrombi, as recently shown using corrosive case techniques in patients with idiopathic portal hypertension (Boyer et al., 1974).

The importance of making the diagnosis of NRH in Felty's patients with oesophageal variceal bleeding is its indication for correct surgical treatment. In the light of our present knowledge, this should optimally be a splenectomy with a shunt procedure or perhaps, in the elderly and severely arthritic patient, a splenectomy alone.

\section{References}

Barnes, C. G., Turnbull, A. L., and Vernon-Roberts, (1971). Felty's syndrome. A clinical and pathological survey of twenty-one patients and their response treatment. Annals of the Rheumatic Diseases, 30, 359-374.

Blendis, L. M. (1978). Liver disease in Felty's syndronge. The association with nodular regenerative hyperplas Postgraduate Medical Journal (in press).

Blendis, L. M., Ansell, I. D., Lloyd Jones, K., Hamilt E. B. D., and Williams, R. (1970a). Liver in Feltfs syndrome. British Medical Journal, 1, 131-135.

Blendis, L. M., Ramboer, C., Banks, D. C., and Williams, $\mathbf{R}$. (1970b). Splenic blood flow in splenomegaly. Clinieal Science, 38, 73-84.

Blendis, L. M. Parkinson, M. C., Shilkin, K. B., and Williangs, R. (1974). Nodular regenerative hyperplasia of the lifer in Felty's syndrome. Quarterly Journal of Medicine, 25-32.

Blendis, L. M., Lloyd Jones, K., Hamilton, E. B. D., a Williams, R. (1976). Familial Felty's syndrome. Annalsinef the Rheumatic Diseases, 35, 279-281.

Boyer, J. E., Hales, M. R., and Klatskin, G. (1974). 'Id $\overrightarrow{\mathscr{G}}$ pathic' portal hypertension due to occlusion of intrahepatic portal veins by organized thrombi. Medicine, 53, 77-91?

Harris, M., Rash, R. M., and Dymock, I. W. (1974). Nodular, non-cirrhotic liver associated with porfall hypertension in a patient with rheumatoid arthritis. Journal of Clinical Pathology, 27, 963-966.

Klofkorn, R. W., Steigerwald, J. S., Mills, D. M., ated Smyth, C. J. (1976). Oesophageal varices in Felty's sydo drome. Arthritis and Rheumatism, 19, 150-154.

Knowles, D. M., Kaye, G. I., and Godman, G. C. (1978). Nodular regenerative hyperplasia of the liver. Gastsenterology, 69, 746-751.

Reisman, T., Levi, J. E., Zeppa, R, Clark, R., Morton, R, and Schiff, E. R. (1977). Non cirrhotic portal hypertensi in Felty's syndrome. American Journal of Digestive Diseases, 22, 145-148.

Ritland, S. (1973). Cirrhosis of the liver in Felty's syndronfir. Scandinavian Journal of Rheumatology, 2, 29-32.

Stauffer, J. Q., Lapinski, M. W., Honold, D. J., and Myer J. K. (1975). Focal nodular hyperplasia of the liver and intrahepatic haemorrhage in young women on ofgit contraceptives. Annals of Internal Medicine, 83, 301-306

Steiner, P. E. (1959). Nodular regenerative hyperplasia American Journal of Pathology, 35, 943-951. 